\title{
Assessment of Laon Management Practice: A Case Study in Commercial Bank of Ethiopia/CBE/, Wolaita Sodo Branch
}

\author{
BIRHANU ALEMU GEBRE \\ Lecturer of Accounting and Finance in Wolaita Sodo University
}

\begin{abstract}
The paper entitled loan management system in Commercial Bank of Ethiopia Woliata sodo branch aimed to assess loan management system of CBE Woliata sodo branch. Purposive sampling technique is used to select 7 employees and 3 credit customers. Both primary and secondary data were collected. Manufacturing sector, Domestic trade sector and Service sectors are the main customers of CBE Woliata Sodo branch. The bank mainly considers business plan, saved capital, financial information and collateral as criteria to approve loan. It followed fixed interest rate policy for both new and existing business a customer that is $9.5 \%$. Supply and demand factor on the market, unexpected decline on price because of global market ,lack of modern management in different business sectors are the factor that influence the loan repayment of customer. The major problems in loan application and repayment process are poor financial record system of the customer, using the approved loan for other purpose, holding the product by expecting to sale with higher price in future and failure to pay on time, lack of credit information of applicants such as collateral, repayment modality and failure to repay the loan as agreement respectively. Finally the researcher suggest that carefully evaluate the collateral to be offered by the business borrowers for getting loan and thoroughly inquire into the reputation and economic position of the borrower, so that the risk of default will be minimized specially in case of new borrowers.
\end{abstract}

Keywords: loan, sectors, loan management etc

DOI: $10.7176 / \mathrm{RJFA} / 10-3-09$

\section{INTRODUCTION}

\section{Back ground}

Loan is an arrangement in which lender gives money or property to borrower and borrower gives to return in the properly or to repay the money usually along with interest at some future date. Usually there is a predetermined time for repaying a loam and generally the lender has to bear the risk that the borrower may not repay. The main objective of the bank is mobilization of fund from national and internal source and provision of long medium and short -term investment credits to achieve its objective the bank as to be sustainable by generating sufficient profit from its operation. This results in effectiveness and efficient of loam able fund mobilization credit provision and ultimate collection of loans, which have direct impact on the bank profitability and liquidity. (R.R.paul, 2003).

Generally loan management system is the process in which manage the loan in proper manner. According to the regulation act, at loan of banking company should be classified as secure and unsecure loan. Secure loans are giving against government securities, shares and debentures to industrial concerns, goods and documents of title to goods, gold bullion and jewelry, real-estate and life of policies. Unsecure are either can advance against the personal credits for the borrowers. They are either can advances against the personal credit worthiness of the borrowers supported by the second signature. (Sherkham,2005).

Each borrower, a loan is debt an obligation to repay the borrower money plus interest. For each lender a loan is an investment for banks perspectives it a loan management system is not properly. Operating the bank would loss both economic and profitable privilege.

\section{Statement of the Problem}

Banking industry from its nature is very wide and modern which has several functions with its structure from the banking perspective. Loans are most assets held by banks and bank lending provides the bulk of bank income. It is equally true that bank loans, as they are profitable, equally risky.

Ethiopia is characterized by under utilization of land, labor and capital and manpower resource. There is a scarcity of capital, lack of investment opportunities that requires credit for establishment and expansion of agricultural, industrial, trading and other sectors with the objective of economic development in a country (EBE credit procedures volume II).

The loan that has been extended to various sectors of the economy must be recorded in full if the objective is circulating more and more financial resources to meet the increasing demand for credit and to keep the bank for lending and the interest to meet the operating costs. The bank collects the principals and interests from the customers (borrowers) on time (Peter Howells and Keith Bain, 2000).

But loans have also higher probability of default than other asset. Even though loans management system plays critical role in the financial performance and well being of banking industry banks sometimes don't 
properly manage the their loan. Absence of proper loans management system will lead to loss of all or part of outstanding loans which are resulted from poor follow ups of manager, price fluctuation, inflation, and other borrower's related problem.

Objective of the Study

The general objective of the study is to assess the loan management practice of CBE in wolaita sodo branch.

\section{Specific Objectives}

* To assess the major problems of loan defaults in the CBE wolaita sodo branch.

* To assess the action the bank takes if the costumer or business defaulted.

* To examine the factor influence the loan repayment trend of costumer.

Sectors Involved in the Study

$>$ Manufacturing sector includes: metal and engineering, textile and garment, leather or educts, wood work productivity, agro-processing and hand craft products and also flour factory.

> Domestic trade sector includes: Domestic products whole sales and retail trade, and coffee suppliers.

$>$ Service sector includes: education, hotel, solid waste collection and racing, maintenance service.

\section{RESEARCH METHODOLOGY}

For the study descriptive research would be used with reference to the transformation of raw data into summary format that will make to the reader easy to understand. The main purpose of such research is describing of the state of nature existing at present. There are only seven employees in credit management department and credit customers from three different sectors (manufacturing, domestic trade and services sectors). The researcher purposively selected the seven credit management department staffs and three credit customers from manufacturing, domestic trade and services sectors (flour factory, coffee supplier and hotel) were sampled to collect primary data.

\section{RESULTS AND DISCUSSION}

Data type that the researcher used is both quantitative and qualitative data. Primary data were collected through interview and open-ended and close-ended questionnaires. SPSS (statistical program for social science) is used for data analysis.

Table 1: Criteria for loan service

\begin{tabular}{lll}
\hline No. & For Existing business & For New business \\
1 & Business plan & Saved capital \\
2 & Financial information & Deposit status of the customer \\
3 & Collateral & Business plan \\
4 & Integrity & Financial information \\
5 & Credit utilization habit or credit exposure & Collateral \\
6 & Tax obligation & - \\
7 & Repayment performance & - \\
\hline
\end{tabular}

(Source: Researcher's own computation)

Criteria for loan service delivery vary for new and existing business firms.

Business plan: A business plan is asset of documents prepared by a firms management to summarize its operational and financial objective for the near future (usually one to three years) and to show how they will be achieved. Business plan is a document demonstrating the feasibility of a prospective new business and providing a road map for its first several years of operation. A business plan is a written statement of your business; what you want to achieve with it and how you will do that. It should outline the structure of your business, the product or services, the customer, the growth potential and financials. But as well as giving information about your business it should also inspire you for the future.

Financial information: Data such as credit card numbers, credit ratings ,account balance and other monetary facts about a person or organization that are used in billing ,credit assessment ,loan transactions, and other financial activities. Financial information must be processed in order for the business to be conducted, but it must also be carefully handled by business in order to ensure security for customers and to avoid the litigation and bad publicity that can stem from negligent or improper use. Financial statements are records that outline the financial activities of a business, an individual or other entity. Financial statements are meant to present the financial information of the entity in question as clearly and concisely as possible for both the entity and for readers. Financial statements for business usually include; income statement, balance sheet, statement of retained earnings and statement of cash flow.

Collateral: collateral is property or other assets that a borrowers offers a lender to secure a loan. The day all the 
loan is paid off by the borrower is the day the home will no longer be collateral, and the lender won't have any rights to the asset. If the borrower stops making the promised loan payments, the lender can seize the collateral to recoup its losses. Because collateral offers some security to the lender in case the borrowers fails to pay back the loan.

Integrity:Integrity means doing the right thing at all times and in all circumstances, whether or not any one is watching. It takes having the courage to do the right thing, no matter what the consequences will be.

Tax obligation: is highly dependent on the specifics of the companies concerned and the tax jurisdictions to which they are subject. Generally tax obligation means that the amount of tax a person or company owes.

Repayment performance is the capacity of the business that performing their debt in maturity date.

Saved capital: the customer debit and credit turnover of the business with the bank or transaction. The times for saving is different due to the nature of business. For example; quarterly base for merchandise business, semiannually base for seasonal business like domestic trade service (coffee supplier), monthly base for consuming goods like soft drink.

\section{Ratio of Collateral to Loan Amount}

It may depend up on the credit risk grade of the customers. The CBE Wolaita Sodo branch in principle follows cash flow based lending system. But collateral is the second factor to mitigate risk.

Therefore, according to the customer credit risk grade, it is different. Those are grade one (1) and two (2) is $75 \%: 100 \%$ or $0.75: 1$, grade three (3) is $85 \%: 100 \%$ or $0.8: 1$ and grade four (4) is $100 \%: 100 \%$ or $1: 1$. But credit risk grade four (4) is used for existing business /customer who have poor performance of loan.

For newly established business /customer, credit risk grade three is applied. This is 100\%:85\% or 1:0.85 collateral coverage is needed from customer's .The credit risk grade of the customer imply that the repayment capacity of customer within due date, to measure the expansion and viability of the business, and how much health creditors to the bank are available.

\section{Loan Term}

For all new and existing business /customer, the repayment period is not done regarding with neither business is new, nor existing rather it focuses various things, such as financial information. Business plan, required approved loan or as per cash flow of the business. For short term period one-three years, for medium term period three-five years and for long term period five-fifteen years. But, the maximum period of any loan should be not exceed fifteen to twenty years for commercial (business loan) and consumer (Condominium) loan respectively. Most of the customer of the bank obtain medium term loan from the bank.

\section{Table 2: Reflection of customer on the loan term}

\begin{tabular}{lll}
\hline Loan term & No. of respondents & Percentage \\
Short term & 1 & $33.33 \%$ \\
Medium term & 2 & $66.67 \%$ \\
Long term & - & \\
Total & 3 & $100 \%$ \\
\hline
\end{tabular}

(Source: Researcher's own computation)

From the above table 4.5 , which indicates the short term loan customer is one ( 1 or $33.33 \%)$ and there are two ( 2 or $66.67 \%$ ) of customers are obtain medium term loan from the CBE Wolaita Sodo branch. There is no customer who obtain long term loan from the bank. Therefore, most of the customers of the bank are obtain medium term loan from the bank.

\section{The Rank of Criteria to Loan Request Approval}

The bank has been ranking the criteria to the approval of loan request. Financial information and business plan of customer are ranked as first and are very important, collateral and saved capital are ranked as second and third criteria for loan approval requests and are important and less important criteria respectively. In addition to this, credit risk grading capacity is also considered.

\section{Interest Rate}

The bank followed fixed interest rate policy for both new applicant and existing business customers, it is $9.5 \%$. But for the government organization such as fertilizer supplier, Omo micro finance, cooperative union and agricultural loan is $7.5 \%$ for both new and existing business firms.

However, $66.67 \%$ of the customer should not satisfy by the interest rate of the bank most of time because it should be high interest rate. The interest rate is $9.5 \%$. But the average interest rate for the private banks is $14 \%$.

\section{Financial Statement}

The income statement, balance sheet and cash flow statement are required from loan applicant. But, statement of 
retain earnings is required for PLC (private limited companies).

Table 3: Approval Period of Loan

Firm's response about the time taken from application to loan approval is as follows:

\begin{tabular}{lll}
\hline Month & No. of respondents & Percentage \\
After one month & 1 & $33.33 \%$ \\
One to three month & 2 & $66.67 \%$ \\
Three month & - & \\
Total & 3 & $100 \%$ \\
\hline
\end{tabular}

(Source: Researcher's own computation)

From the above table 4.6, which indicates the approval period of loan, one ( 1 or $33.33 \%)$ of the customers are received after one month, and two (2 or 66.67\%) of customers are received one to three months. Therefore, as indicated above the bank approval period of loan is one to three months $(66.67 \%)$.

\section{Interest Computation}

The bank began the interest computation for customers are immediately after loan provision period of time .But, for domestic trade the interest computation wait up to the business generate cash birr amount and only the principal amount is paid. The time of the business generation cash birr amount is based on the business nature and the capacity of business well performing of the customer.

\section{Repayment Period}

The repayment period of the loan is began depends up on the loan agreement between the customers and bank, type of loan, type of project, the nature of the business, credit decision on repayment modality. But, for the domestic trade services, the repayment period begins when business generate cash birr amount. In addition to this, the bank has begun the repayment from customers quarterly, semi-annually and annually basis, based on the agreement made between customer and bank.

\section{Training or Awareness Given}

Most of the time, the bank give to borrowers an awareness on the usage of loan, but not give any training to their customers on the proper use of loan. As the evidence indicates $66.67 \%$ the bank gives awareness to their customers on the proper use of loan. Therefore, the figure indicates that the bank give awareness in some extent to its customers on proper usage of loan but not give training.

In other side, the customer idea on training /awareness, indicates that from the bank there is no any training /awareness given on the usage of loan to customers without giving credit/without giving borrowing- as indicates guidance gathered from data $100 \%$ of customer reflect their ideas as not given any training /awareness from the bank to customer on usage of loan provided.

\section{Major Problems in Loan Management}

The major problems in loan application and repayment process are poor financial record system of the customer, using the approved loan for other purpose, holding the product by expecting to sale with higher price in future and fail to pay on time, lack of credit information of applicants such as collateral, repayment modality and failure to repay the loan as agreement respectively.

\section{Effective Sector on Returning Loan}

All sector needed for study are effective on returning of their loan on the specified period of time. Those are domestic trade sector (coffee supplier), manufacturing sector (flour factory) and service sector (hotel) all these are effective on returning of loan respectively.

\section{Factors that Influence the Loan Repayment Trend}

The factors that influence the loan repayment trend of the customer are supply and demand factor on the market. Unexpected decline on price because of global market, lack of modern management in different business sector (customer), high amount of stock (inventory) which is not converted into cash when it is needed and the bank problem specially on recruiting the potential customer (borrower) for their own.

\section{The Bank action takes during business default.}

The action the bank takes if the customers (business) defaulted are the manager contact borrower by telephone and visit them, negotiation, written notice to the borrower to auditing them to immediate repayment shall be made and etc. Also the bank rescheduling the loan repayment period (give) some additional repayment period to their customer. But, this situation happens if and only if the customer's integration with the bank is high. At the end if the customer did not agree with above solution the bank has its own procedure to sale the property of the 
applicant.

\section{Bank procedures during default}

$1^{\text {st }}$. Transfer the case to loan recovery them.

$2^{\text {nd }}$. The bank will gave the power to sell the property on the applicant as per proclamation no. 97/90.

$3^{\text {rd }}$. To sell the property declared the announcement through news paper and TV.S or other media for bid.

$4^{\text {th }}$. If the property is not sufficient enough to settle the loan, the bank search any other property of customer (business).

$5^{\text {th }}$. If the property of the borrower totally not sufficient to cover the granted loan, the bank will treat the loan as its expense (cost) and finally the loan will be settled through debiting expense.

\section{CONCLUSION}

This study tried to assess the loan management system of CBE particularly the CBE Wolaita Sodo branch and investigated the cause for default of loan management system and its effect. Furthermore, the following conclusions are made:

$>$ Timely planned recovery of loans contributes the profitability as well as financial stability of any lending institution.

$>$ The result/finding indicates that the loan was important for all business sectors.

$>$ The main importance of the loan given to the customers is addressing the problem to keep the living standard of the customer and increasing the development of the nation as well.

$>$ The interest rates of CBE wolaita sodo branch are fair if it is compared with other privat bank. How much is others?

$>$ Most of the time, the bank gives awareness to the borrower on the usage of loan, but not give any training to its customer. In other side, customer idea on training /awareness indicates that from the bank there is no any training /awareness given on the usage of loan to customer without giving credit.

$>$ The manager contact of the credit customers via telephone, visiting physically, negotiation, rescheduling the loan repayment period and giving additional repayment period are actions taken to avoid business default.

\section{Recommendation}

The following recommendations could be forwarded to the bank and customers in order to improve the loan management system of the bank:

* The bank better widely provide long term loan in addition to the medium loan to satisfy customer needs.

* It is advisable to the bank to charge different interest rate to different sectors,

* The bank better respond to loan request with in short period of time.

* provision of training and awareness on loan management to customers is better enhanced by the bank to improve customer loan management problems,

* setting dissimilar loan term for new business and existing business is recommendable to the bank,

* Enhancing business performance is advisable to credit customers because it will influence ratio of collateral loan amount,

* Improving the book keeping and business management practice is recommendable to the customers to further acceptance of their loan request,

* Customers better use the loan for its approved purpose,

\section{References}

Peter Howells and Keith Bain (2000), Financial markets and Institution, $3^{\text {rd }}$ edition, USA.

R.R. Paul (2003), Money banking and international trade, $5^{\text {th }}$ edition, India. 